\title{
HUBUNGAN MATA PELAJARAN PANCASILA DI SEKOLAH TERHADAP IMPLEMENTASI PANCASILA PADA PELAJAR
}

\author{
Nisa', Fatihatun ${ }^{1}$, Hanifa Rizqi ${ }^{2}$, Yuana Berlianti ${ }^{3}$ \\ Politeknik Pembangunan Pertanian Yogyakarta Magelang \\ fatihatunnisa538@gmail.com, hanifalarasati2704@gmail.com, yuanaberlianti@gmail.com
}

\begin{abstract}
ABSTRAK
Pancasila merupakan dasar negara Indonesia yang dijadikan sebagai pedoman hidup warga negara Indonesia. Penerapan nilai-nilai pancasila dikalangan pelajar menjadi hal yang penting dan tidak bisa disepelekan. Penelitian ini bertujuan untuk 1) Mengetahui implementasi nilai-nilai pancasila dalam kehidupan di lingkungan sekolah, 2) Mengetahui apakah mata pelajaran Pancasila penting dan harus tetap ada dalam mata pelajaran wajib di sekolah, 3) Mengetahui apakah nilai-nilai pancasila masih perlu dipertahankan. Sejalan dengan tujuan penelitian tersebut, maka dalam penelitian ini menggunakan metode penelitian deskriptif kualitatif. Subyek penelitian sebanyak 27 pelajar di Kabupaten Purworejo. Metode pengumpulan data menggunakan survei dengan menyebar google formulir. Hasil penelitian sebagai berikut; 1) Mayoritas pelajar di Kabupaten Purworejo, Jawa Tengah sudah mengimplementasikan nilai-nilai sila Pancasila dalam kehidupan sehari-hari. 2) Pelajaran Pancasila sangat berperan penting dalam pendidikan karakter pelajar sehingga mata pelajaran pancasila sangat perlu diterapkan di sekolah sebagai mata pelajaran wajib. 3) Nilai-nilai Pancasila masih perlu dipertahankan sebagai karakter dan budaya bangsa. Dengan adanya pendidikan Pancasila, pelajar dapat mengetahui dasar negara, pedoman hidup dan implementasi dari nilai-nilai Pancasila yang masih perlu dipertahankan.
\end{abstract}

Kata kunci : Pancasila, pelajaran, pelajar.

\begin{abstract}
Pancasila is the basis of the Indonesian state which serves as a guide for the life of Indonesian citizens. The application of Pancasila values among students is important and cannot be underestimated. This study aims to 1) Know the application of Pancasila values in the school environment, 2) Determine whether Pancasila subjects are important and must remain in compulsory subjects in schools, 3) Knowing whether Pancasila values still need to be maintained. In line with the research objectives, this study uses a qualitative descriptive research method. The research subjects were 27 students in Purworejo Regency. Methods of data collection using a survey by spreading google forms. The results of the study are as follows; 1) The majority of students in Purworejo Regency, Central Java have implemented the values of the Pancasila principles in their daily life. 2) Pancasila lessons play an important role in character education of students so that Pancasila subjects need to be applied in schools as compulsory subjects. 3) Pancasila values still need to be preserved as the national character and culture. With the existence of Pancasila education, students can know the basis of the state, life guidelines and implementation of Pancasila values that still need to be maintained.
\end{abstract}

Keywords : Pancasila, lesson, learner.

\section{PENDAHULUAN}

Pancasila merupakan dasar negara Indonesia. Pancasila berasal dari bahasa Sanskerta yang terdiri dari dua kata, yaitu Panca (lima) dan Sila (prinsip/asas), artinya ada lima prinsip atau asas penting rakyat Indonesia dalam kehidupan berbangsa dan bernegara. Kelima sila 
tersebut ialah Ketuhanan yang Maha Esa, Kemanusiaan yang adil dan beradab, Persatuan Indonesia, Kerakyatan yang dipimpin oleh hikmat kebijaksanaan dalam permusyawaratan/ perwakilan, dan Keadilan sosial bagi seluruh rakyat Indonesia.

Pancasila sebagai dasar dan ideologi negara berasal dari usulan para tokoh pendiri bangsa. Nilai-nilai pancasila merupakan nilai luhur yang berakar dari kebudayaan masyarakat terdahulu. Pancasila sangat melekat dengan kepribadian bangsa Indonesia. Oleh sebab itu, Pancasila tidak dapat diubah oleh siapapun dan kapanpun. Di era globalisasi ini peran pancasila sangat penting bagi pelajar untuk menjaga kepribadian bangsa Indonesia, karena adanya globalisasi batasan - batasan antarnegara tidak terlihat, sehingga berbagai budaya asing dapat masuk dengan mudah dan memengaruhi pola pikir dan kehidupan pelajar. Hal ini dapat memberikan dampak positif dan negatif bagi bangsa Indonesia. Apabila pelajar dapat menyaring budaya yang masuk, maka berbagai hal positif akan diperoleh seperti menambah wawasan dan mempererat hubungan antarbangsa dan negara, sedangkan hal negatif dampak globalisasi yaitu merusak moral bangsa Indonesia.

Salah satu permasalahan yang muncul pada kalangan pelajar saat ini yaitu menurunnya rasa nasionalisme dan petriotisme jiwa pancasila. Hal ini karena semakin banyaknya budaya asing yang masuk sehingga memengaruhi pola pikir dan kebiasaan yang kurang baik. Kebanyakan pelajar beranggapan bahwa budaya asing merupakan budaya yang modern dibandingkan budaya sendiri atau budaya daerah. Hal ini berakibat nilai-nilai luhur bangsa Indonesia atau nilai-nilai pancasila hampir diabaikan di kalangan pelajar. Berbagai masalah muncul akibat menurunnya rasa nasionalsme dan patriotisme di kalangan pelajar, banyak pelajar yang mengalami disorientasi, dislokasi, dan terlibat pada suatu kepentingan yang hanya mementingkan diri sendiri atau kelompok tertentu.

Pancasila berperan penting dalam kehidupan berbangsa dan bernegara yaitu sebagai pedoman hidup, pancasila menjadi sumber ideologi yang mengatur tata kehiduan masyarakat Indonesia. Pancasila sebagai pedoman hidup bangsa Indonesia berfungsi sebagai acuan atau pegangan bagi masyarakat khususnya pelajar dalam bertingkah laku. Hal ini berkaitan erat dengan etika pelajar di lingkungan sekolah, tentang apa yang selayaknya dikerjakan dan yang selayaknya dihindari.

Pancasila mengandung nilainilai yang dapat meningkatkan rasa nasionalisme dan patriotisme generasi muda di era globalisasi khususnya untuk para pelajar. Maka dari itu, peneliti tertarik untuk menggali lebih dalam tentang bagaimana penerapan nilai-nilai pancasila dalam kehidupan pelajar, apakah mata pelajaran pancasila penting dan harus ada, serta apakah nilai-nilai pancasila masih perlu diadakan.

Sehubungan dengan latar belakang di atas, masalah penelitian ini dirumuskan sebagai berikut : 
1. Bagaimana implementasi nilainilai pancasila dalam kehidupan pelajar di lingkungan sekolah?

2. Apakah mata pelajaran Pancasila penting dan harus tetap ada dalam mata pelajaran wajib di sekolah?

3. Apakah nilai-nilai Pancasila masih perlu dipertahankan?

Berdasarkan rumusan masalah tersebut, tujuan yang diharapakan yaitu

1. Mengetahui implementasi pancasila nilai-nilai pancasila dalam kehidupan di lingkungan sekolah

2. Mengetetahui apakah mata pelajaran Pancasila penting dan harus tetap ada dalam mata pelajaran wajib di sekolah.

3. Mengetahui apakah nilai-nilai pancasila masih perlu dipertahankan?

\section{METODE}

Penelitian dilaksanakan pada bulan Februari 2021 pada siswa siswi SMA di Kabupaten Purworejo, Jawa Tengah. Penentuan sampel dilakukan dengan cara random sampling pada siswa siswi. Metode pengumpulan data yang digunakan dalam penelitian ini adalah metode survei, yaitu penelitian yang dilakukan untuk memperoleh fakta-fakta atau gejala yang ada dalam mencari keterangan secara fakta dalam dunia pendidikan dan sosial. Untuk menunjang penelitian ini, maka peneliti melakukan pengumpulam data yang dipeoleh dari data primer melalui penyebaran google formulir. Data sekunder diperoleh dari literature pustaka dan lembagalembaga atau instansi yang terkait, baik instansi pemerintah maupun swasta.

Metode analisis data yang digunakan adalah metode deskriptif kualitatif yaitu dengan menghimpun data google formulir hasil isian responden kemudian menganalisis. Metode deskriptif kualitatif merupakan sebuah metode penelitian yang memanfaatkan data kualitatif dan dijabarkan secara deskriptif untuk menganalisis keadaan secara sosial. Jenis penelitian deskriptif kualitatif menampilkan hasil data apa adanya tanpa proses manupulasi atau perlakuan lain.

Peneliti menyebar google formulir dengan memberikan pertanyaan terkait implementasi pancasila pada tabel 1 .

Tabel 1. Item pertanyaan

\begin{tabular}{|c|l|}
\hline No & \multicolumn{1}{|c|}{ Item Pertanyaan } \\
\hline 1. & Apakah anda sudah melaksanakan ibadah sesuai agama masing-masing? \\
\hline 2. & Apakah sekolah kalian mengadakan kegiatan keagamaan? \\
\hline 3. & Apakah anda pernah mengganggu teman ketika Anda sedang beribadah? \\
\hline 4. & $\begin{array}{l}\text { Jika agamamu mayoritas, apakah Anda akan mengucilkan agama yang } \\
\text { minoritas? }\end{array}$ \\
\hline 5. & $\begin{array}{l}\text { Apakah Anda akan menyisihkan uang saku unntuk membantu korban } \\
\text { bencana? }\end{array}$ \\
\hline 6. & Apakah Anda akan membantu teman Anda yang sedang kerepotan \\
\hline
\end{tabular}




\begin{tabular}{|c|l|}
\hline & $\begin{array}{l}\text { membawa buku, sedangkan Anda ada keperluan dan teman Anda tidak } \\
\text { meminta pertolongan Anda? }\end{array}$ \\
\hline 7. & Apakah Anda menggunakan bahasa yang sopan dalam bergaul? \\
\hline 8. & $\begin{array}{l}\text { Apakah Anda tertarik dengan kegiatan kesenian yang diselenggarakan } \\
\text { sekolah? }\end{array}$ \\
\hline 9. & Apakah Anda mengikuti upacara di sekolah dengan senang hati? \\
\hline 10. & Apakah Anda berpartisipasi dalam pemilihan ketua osis? \\
\hline 11. & $\begin{array}{l}\text { Jika ada tugas kelompok, apakah Anda menyampaikan pendapat Anda } \\
\text { dalam diskusi? }\end{array}$ \\
\hline 12. & $\begin{array}{l}\text { Jika hasil diskusi tidak sesuai dengan pendapat Anda, apakah Anda akan } \\
\text { menerima dengan lapang dada? }\end{array}$ \\
\hline 13. & $\begin{array}{l}\text { Apakah Anda akan menerima sanksi hukuman atas kesalahan Anda dan } \\
\text { menyadari perbuatan Anda? }\end{array}$ \\
\hline 14. & $\begin{array}{l}\text { Jika ada tugas dari guru untuk membuat kerajinan tangan, apakah Anda } \\
\text { akan mengapresiasi hasil karya teman Anda? }\end{array}$ \\
\hline 15. & $\begin{array}{l}\text { Apabila teman Anda yang tidak bersalah dikenai hukuman, dan ternyata } \\
\text { Anda yang bersalah, apakah Anda akan mengakui kesalahan tersebut dan } \\
\text { menjalankan hukuman? }\end{array}$ \\
\hline 16. & $\begin{array}{l}\text { Apakah mata pelajaran pancasila penting dan harus tetap ada dalam mata } \\
\text { pelajaran wajib di sekolah? } \\
\text { (beserta alasannya) }\end{array}$ \\
\hline 17. & $\begin{array}{l}\text { Apakah nilai-nilai pancasila masih perlu dipertahankan? } \\
\text { (beserta alasannya) }\end{array}$ \\
\hline 18. & $\begin{array}{l}\text { Menurut Anda, apa manfaat menerapkan nilai-nilai pancasila dalam } \\
\text { kehidupan? }\end{array}$ \\
\hline
\end{tabular}

Gambar 1. Suasana pelajar di Kabupaten Purworejo

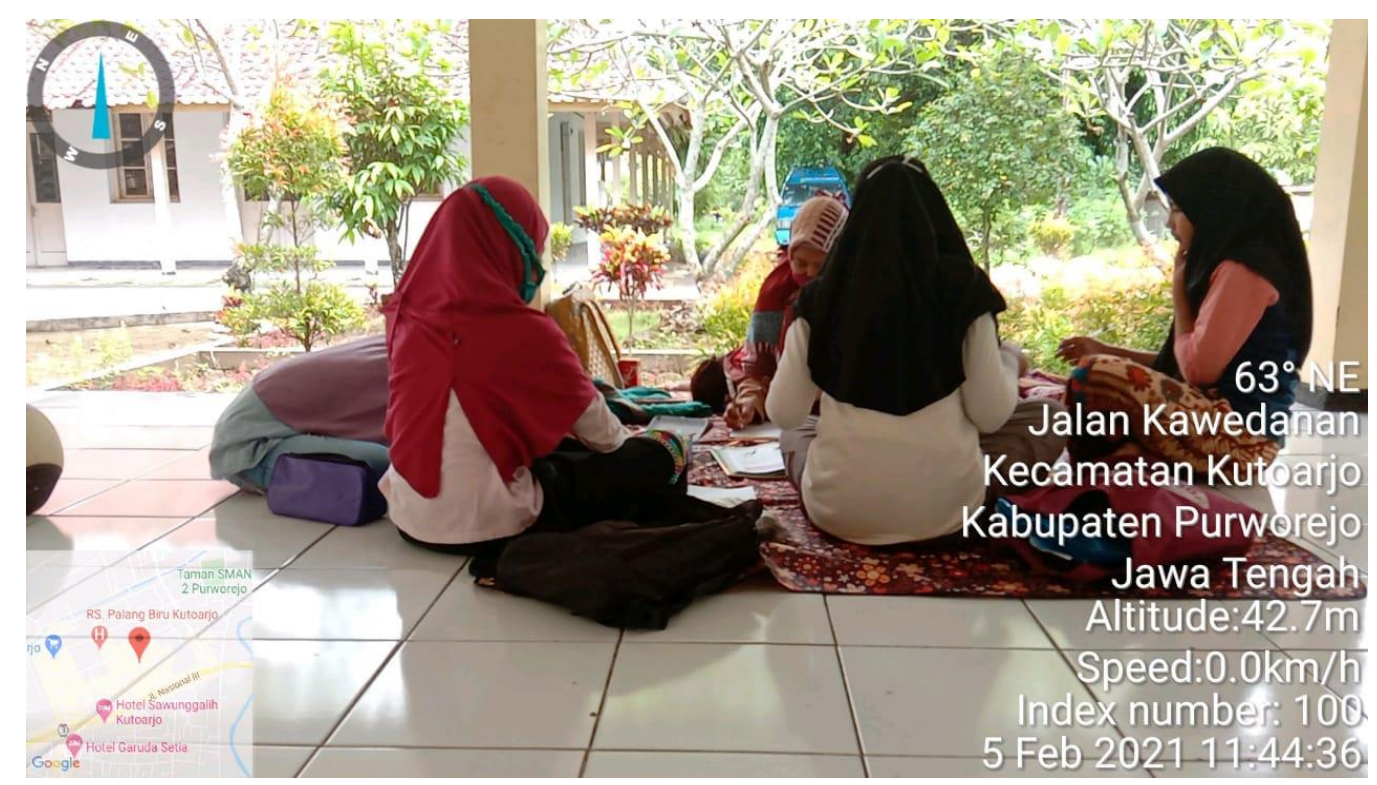

Sumber : dokumen peneliti, 5 Februari 2021. 
HASIL DAN PEMBAHASAN

Dalam pembukaan UndangUndang Dasar Negara Republik Indonesia Tahun 1945 alenia keempat terdapat rumusan Pancasila sebagai dasar negara Indonesia. Rumusan Pancasila itulah dalam hukum positif Indonesia secara yuridis-konstitusional sah, berlaku, dan mengikat seluruh lembaga negara, lembaga masyarakat, dan setiap warga negara, tanpa kecuali. Rumusan Pancasila yang terdapat pada Pembukaan Undang-Undang Dasar Negara Republik Indonesia Tahun 1945, dimana pembukaan tersebut sebagai hukum derajat tinggi yang tidak dapat diubah secara hukum positif, maka Pancasila sebagai dasar negara Indonesia bersifat final dan mengikat bagi seluruh penyelenggara negara.

Nilai-nilai Pancasila merupakan suatu pandangan hidup bangsa Indonesia yang memiliki nilai-nilai sesuai dengan hati nurani bangsa Indonesia, karena bersumber pada kepribadian bangsa. Dalam kehidupan kenegaraan, perwujudan nilai Pancasila harus tampak dalam suatu peraturan perundangan yang berlaku di Indonesia. Karena dengan tampaknya Pancasila dalam suatu peraturan dapat menuntun seluruh masyarakat untuk bersikap sesuai dengan peraturan perundangan yang disesuaikan dengan Pancasila.

Adapun nilai-nilai yang terkandung dalam setiap sila Pancasila adalah sebagai berikut:

1. Ketuhanan Yang Maha Esa

Dalam sila ketuhanan
mengandung nilai keyakinan
beragama, bahwa Negara yang
didirikan adalah sebagai
pengejawantahan tujuan manusia
sebagai makhluk Tuhan yang Maha

Esa untuk selalu menjunjung tinggi sikap keyakinan dalam beribadah terhadap agama yang diyakini secara penuh.. Oleh karena itu segala hal yang berkaitan dengan pelaksanaan dan penyelengaraan Negara bahkan moral Negara, moral penyelengara Negara, politik Negara, pemerintahan Negara, hukum dan peraturan perundngundangan Negara, kebebasan dan hak asasi warga Negara harus dijiwai nilainilai Ketuhanan Yang Maha Esa.

2. Kemanusiaan yang Adil dan Beradab Dalam sila kemanusiaan terkandung nilai bahwa negara harus menjunjung tinggi harkat dan martabat manusia sebagai makhluk yang beradab. Sila kedua Pancasila mengandung nilai suatu kesadaran sikap moral dan tingkah laku manusia yang didasarkan pada norma-norma dan kebudayaan baik terhadap diri sendiri, sesama manusia, maupun terhadap lingkungannya.

3. Persatuan Indonesia

Dalam sila ketiga tercermin sebuah nilai kesatuan bangsa Indonesia yang utuh dan satu. Misalnya dalam gotong-royong dalam kegiatan di sekitar lingkungan. Sifat kodrat manusia monodualis yaitu sebagai makhluk individu dan sebagai makhluk sosial. Untuk itu manusia memiliki perbedaan individu, suku, ras, kelompok, golongan, maupun agama. Konsekuensinya di dalam Negara adalah beraneka ragam tetapi mengkatkan diri dalam suatu kesatuan dalam semboyan "Bhineka Tunggal Ika". 
4. Kerakyatan yang Dipimpin oleh Hikmat Kebijaksanan dalam Permusyawaratan/Perwakilan

Rakyat merupakan subjek pendukung pokok Negara. Negara merupakan dari rakyat, oleh rakyat, dan untuk rakyat sehingga rakyat merupakan asal mula kekuasaan Negara. Dalam sila keempat terkandung nilai demokrasi yang harus dilaksanakan dalam kehidupan negara.

5. Keadilan Sosial bagi Seluruh Rakyat Indonesia

Sila kelima mengandung makna keadilan. Keadilan disini sangat luas dan tidak terbatas dalam penjabarannya.

Konsekuensi nilai keadilan yang harus terwujud adalah: 1) keadilan distributif (hubungan keadilan antara Negara terhadap warga negaranya), (2) keadilan legal (keadilan antara warga Negara terhadap negara), dan (3) keadilan komutatif (hubungan keadilan antara warga negara satu dengan lainnya).

Nilai-nilai Pancasila adalah sumber dari karakter bangsa, budaya dan pendidikan yang harus diwujudkan dalam kehidupan masyarakat luar tanpa terkecuali khususnya pelajar yang akan menjadi generasi muda bangsa Indonesia. Perwujudan nilai-nilai Pancasila dalam membangun moral peserta didik di lingkungan pendidikan di sekolah yaitu pancasila dijadikan sebagai sumber pendididkan karakter.

Penerapan nilai-nilai Pancasila oleh lembaga pendidikan terhadap peserta didik sangat penting, dan yang pertama adalah membangun moral peserta didik dengan bertujuan sesuai dengan karakter bangsa yang tertuang di dalam Pancasila. Oleh karena itu generasi penerus khususnya peserta didik harus mempunyai ilmu pengetahuan yang luas untuk bisa mempertahankan nilai Pancasila dan mempunyai filter terhadap budaya luar. berhubungan dengan hal tersebut maka pendidikan di butuhkan sebagai sarana pembangunan karakter dan intelektual agar peserta didik mampu menjadi masyarakat Indonesia yang baik, dan sesuai dengan tujuan sisdiknas.

\section{Hasil Penelitian}

Berdasarkan hasil google formulir yang peneliti sebarkan pada tanggal 4 Februari 2021, sebanyak 27 responden dari kalangan pelajar, dapat diketahui bahwa hampir 100\% pelajar telah menerapkan nilai-nilai pada sila pancasila. Pada nilai sila satu yaitu Ketuhanan Yang Maha Esa, $100 \%$ responden telah melaksanakan ibadah sesuai agama masing - masing, 97\% sekolah pernah mengadakan kegiatan keagamaan, $100 \%$ responden tidak mengucilkan agama yang berbeda, dan $63 \%$ responden tidak pernah mengganggu orang yang sedang beribadah. Ini merupakan penerapan nilai sila satu pada pancasila yang bagus, namun masih terdapat sebagian kecil pelajar belum menerapkan nilai sila satu pancasila tersebut karena kurangnya pemahaman mengenai nilai ke-1 pancasila.

Pada penerapan sila kedua yaitu Kemanusiaan yang adil dan beradab, berdasarkan pertanyaan yang peneliti ajukan didapatkan $97 \%$ responden bersedia membantu korban bencana, $60 \%$ responden 
bersedia membantu teman yang kerepotan tanpa dimintai tolong. Hal tersebut membuktikan bahwa pelajar telah memiliki rasa kemanusiaan dan empati yang cukup baik, namun tingkat kepekaan masih perlu ditingkatkan.

Nilai sila ketiga Pancasila yaitu Persatuan Indonesia, berdasarkan survei yang peneliti lakukan, $\quad 89 \%$ responden menggunakan bahasa yang sopan dalam bergaul, $74 \%$ responden tertarik dengan kegiatan kesenian yang diselenggarakan sekolah, 77\% responden mengikuti upacara dengan senang hati. Dengan angka tersebut, dapat disimpulkan bahwa mayoritas pelajar telah mengamalkan nilai sila ketiga dengan baik, namun masih banyak pelajar yang belum menerapkan ketiga contoh penerapan nilai sila ketiga Pancasila.

Pengamalan sila keempat Pancasila yang berbunyi Kerakyatan yang dipimpin oleh hikmat kebijaksanaan dalam permusyawaratan/ perwakilan. Berdasarkan survey contoh pengamalan yang peneliti tanyakan yaitu $100 \%$ responden telah berpartisipasi dalam pemilhan ketua OSIS , $100 \%$ responden terlibat dalam diskusi kelompok, 93\% responden mau menerima dengan lapang dada jika hasil diskusi tidak sesuai kehendak mereka, dan 100\% responden mau menerima sanksi hukuman atas kesalahan yang diperbuat. Hal ini membuktikan bahwa hampir $100 \%$ responden telah mengamalkan nilai-nilai pancasila, namun masih ada 7\% responden yang belum mau menerima keputusan dengan lapang dada ketika hasil keputusan tidak sesuai dengan kehendaknya.
Pengamalan nilai sila kelima Pancasila yaitu Keadilan Sosial Bagi Seluruh Rakyat Indonesia, 100\% bersedia menerima sanksi hukuman atas kesalahan, 96\% responden akan mengapresiasi hasil karya teman, dan 96\% akan bertanggung jawab terhadap kesalahannya. Hal tersebut membuktikan bahwa hampir semua pelajar telah menerapkan nilai sila ke-5 Pancasila sebagai landasan beretika.

Berdasarkan data peneliti, $100 \%$ responden menjawab bahwa mata pelajaran Pancasila sangat penting dan harus tetap ada dalam mata pelajaran wajib di sekolah karena melalui mata pelajaran Pancasila dapat menanamkan karakter dan jati diri bangsa kepada generasi muda agar tidak luntur oleh arus globalisasi, pelajar dapat memahami kondisi dan wawasan kebangsaan Indonesia, sehingga dapat terwujud rasa cinta tanah air serta nasionalis. Pendidikan Pancasila dapat menekankan eksistensi manusia sesuai dengan kodratnya sebagai makhluk multidimensi yang religiu-etis, rasional-kritis, dan komprehensif dalam memandang berbagai persoalan kehidupan berbangsa bernegara, selain itu pelajar diharapkan dapat mewujudkan nilainilai pancasila serta kesadaran berbanga dan bernegara dalam menerapkan ilmunya dengan rasa penuh tanggung jawab, baik kepada sesame manusia maupun Tuhan. Apabila para pelajar telah memahami niai-nila dasar Pancasila melalui pendidikan Pancasila, maka besar kemungkinan para pelajar dapat terus menjaga nilai-nilai luhur Pancasila dan tidak terpengaruh oleh pahampaham ideologi baru yang mencoba untuk menggantikan pancasila. 
Tabel 2. Data responden gform peneliti

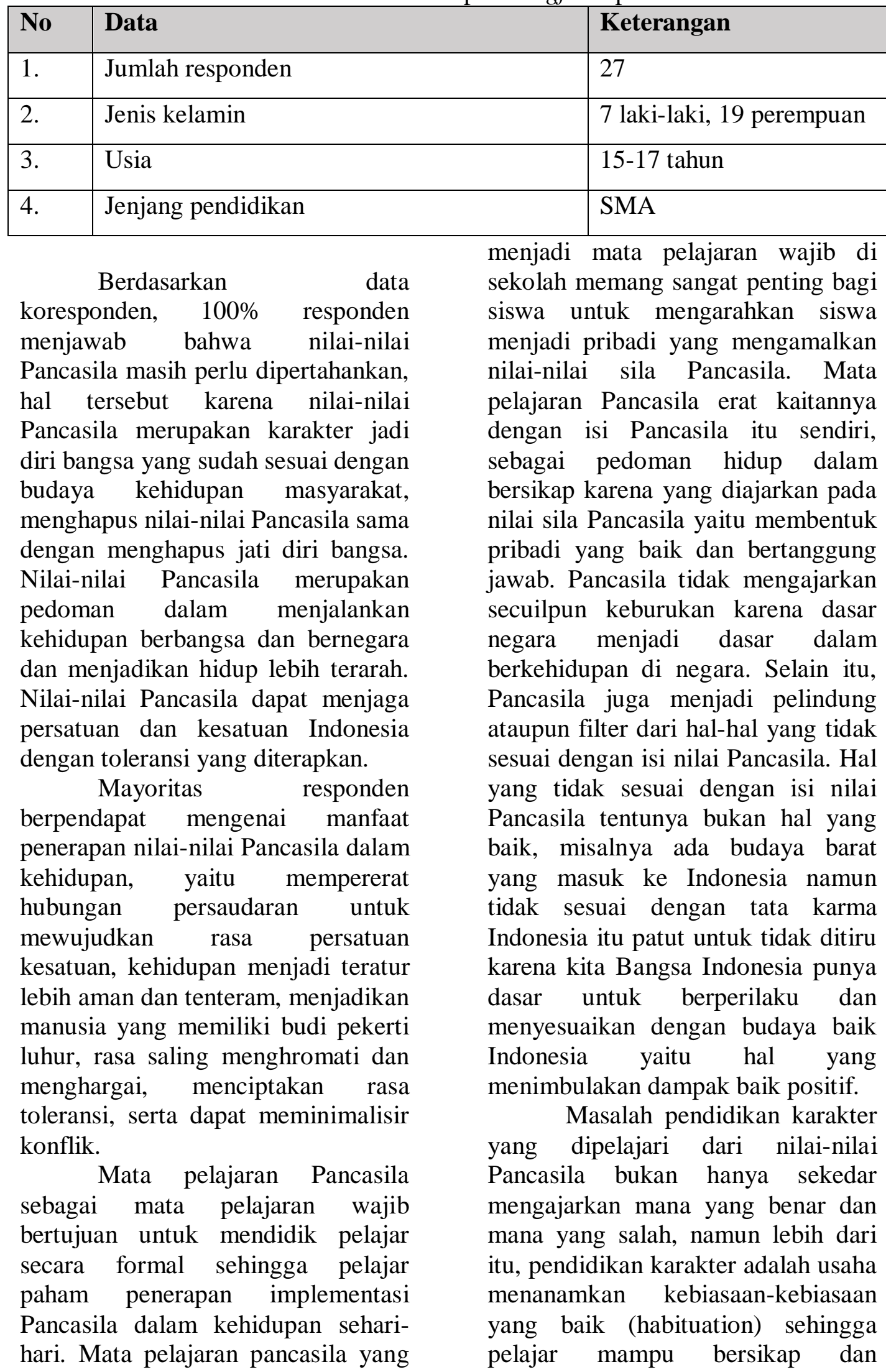


bertindak berdasarkan nilai-nilai yang telah menjadi kepribadian baik sebagai warga negara maupun individu. Nilai-nilai Pancasila sebagai falsafah hidup bangsa perlu diimplementasikan untuk membangkitkan karakter bangsa yang semakin menurun. Pancasila merupakan refleksi kritis dan rasional sebagai dasar negara dan kenyataan budaya bangsa, dengan tujuan untuk mendapatkan pokokpokok pengertiannya secara mendasar dan menyeluruh. Pancasila sebagai ideologi baik dalam pengertian ideologi negara atau ideologi bangsa masih dipertahankan.

\section{KESIMPULAN}

Berdasarkan

tujuan penelitian, dari penelitian ini dapat disimpulkan bahwa hampir seluruh responden pelajar SMA di Kabupaten Purworejo, Jawa Tengah sudah mengimplementasikan nilainilai Pancasila pada kehidupan sehari-hari khususnya di ligkungan sekolah. Pelajaran Pancasila sangat berperan penting dalam pendidikan karakter pelajar. Pelajaran Pancasila masih diperlukan dan masih perlu diterapkan di sekolah sebagai mata pelajaran wajib. Melalui mata pelajaran Pancasila, pelajar dapat mengetahui landasan bernegara serta etika dan karakter yang berbudi pekerti luhur untuk mempertahankan kesatuan dan persatuan bangsa. Dengan mempelajari Pancasila, pelajar dapat mengetahui isi nilainilai Pancasila serta wawasan kebangsaan Indonesia, sehingga dapat mengiplementasikan dalam kehidupan sehari-hari. Dengan adanya pendidikan Pancasila, diharapkan pelajar dapat mempertahankan nilai luhur karakter bangsa.
Nilai-nilai Pancasila sebagai karakter dan budaya suatu bangsa harus dipertahankan, hal tersebut agar dapat dibedakan antara bangsa yang satu dengan yang lainnya. Untuk mempertahankan eksistensi bangsa Indonesia perlu melakukan pembangunan karakter yang merupakan upaya perwujudan amanat Pancasila dan Pembukaan UUD 1945. Pendidikan karakter yang baik harus melibatkan pengetahuan yang baik (moral knowing), perasaan yang baik atau loving good (moral feeling) dan perilaku yang baik (moral action) sehingga terbentuk perwujudan kesatuan perilaku dan sikap hidup pada pelajar.

\section{DAFTAR PUSTAKA}

Adhayanto, O. (2015). Implementasi Nilai-Nilai Pancasila Sebagai Dasar Negara Dalam Pembentukkan Peraturan Perundang-Undangan. Jurnal Ilmu Hukum, 6(2), 166-174.

Efendi, Y., \& Sa'diyah, H. (2020).

Penerapan Nilai-Nilai

Pancasila Dalam Lembaga Pendidikan. JPK (Jurnal Pancasila dan

Kewarganegaraan), 5(1), 5465.

Latif, Y. (2013). Membumikan Etika Pancasila

Dalam

Penyelenggaraan

Negara. Prosiding Kongres Pancasila V 2013: Strategi Pembudayaan Nilai-nilai Pancasila dalam menguatkan semangat ke-Indonesia-an, 72.

Rachmah, H. (2016). Nilai-nilai dalam pendidikan karakter bangsa yang berdasarkan 
Pancasila dan UUD 1945. EJournal WIDYA NonEksakta, 1(1), 7-14.

\section{UCAPAN TERIMA KASIH}

Dengan selesainya penyusunan Jurnal Pancasila dan Bela Negara pada Volume 1, Nomor 1, Edisi Februari 2021 ini penulis menyampaikan terima kasih kepada :

1. Allah SWT yang tel.ah memberikan berkah-Nya sehingga dapat menyusun Jurnal Pancasila dan Bela Negara dengan judul "Hubungan Mata Pelajaran Pancasila terhadap Penerapan Implementasi Sila Pancasila".

2. Orang tua kami yang memberikan dukungan baik moral, spiritual maupun material hingga terselesainya jurnal ini.

3. Bapak Dr. Hastangka, M.Phill selaku dosen pembimbing mata kuliah Pendidikan Pancasila.

4. Seluruh teman yang telah memberikan bantuan berupa pengisian google formulir untuk melakukan survey langsung tentang implementasi sila-sila pancasila di lingkungan sekolah.

5. Kepada pihak-pihak yang belum tercantum diatas penulis mengucapkan terima kasih. 